\title{
High Growth and Low Consumption in East Asia: How to Improve Welfare While Avoiding Financial Failures
}

Andrew Feltenstein, Céline Rochon, and Maral Shamloo 



\title{
IMF Working Paper
}

IMF Institute

\section{High Growth and Low Consumption in East Asia: How to Improve Welfare While Avoiding Financial Failures ${ }^{1}$}

\author{
Prepared by Andrew Feltenstein, Céline Rochon, and Maral Shamloo ${ }^{2}$
}

December 2007

\begin{abstract}
This Working Paper should not be reported as representing the views of the IMF. The views expressed in this Working Paper are those of the author(s) and do not necessarily represent those of the IMF or IMF policy. Working Papers describe research in progress by the author(s) and are published to elicit comments and to further debate.
\end{abstract}

This paper analyzes certain policies that are typical of a number of rapidly growing East Asian countries in which a fixed exchange rate, combined with a surplus labor market, has made domestic assets relatively inexpensive, generating high rates of FDI as well as domestic capital formation. This "investment hunger" can lead to unanticipated declines in the returns to investment, and resulting financial insolvencies. Private consumption remains low and there are concerns that high savings rates cannot be sustained.

We construct a dynamic general equilibrium model and apply it to a stylized Asian economy, loosely based upon China. We calibrate a benchmark equilibrium, and carry out various counterfactual simulations to analyze alternative policies, in particular tax cuts and exchange rate revaluations, as instruments in increasing private consumption while avoiding bank failures.

JEL Classification Numbers: D58, E44, F37, G21

Keywords: Growth, Financial failures, China, General equilibrium

Author's E-Mail Addresses: afeltenstein@imf.org; Celine.Rochon@sbs.ox.ac.uk; M.Shamloo@LSE.ac.uk

\footnotetext{
${ }^{1}$ The authors would like to thank Joshua Aizenmann, Emine Boz, Enrica Detragiache, Philippe Karam, Shigeru Iwata, Leslie Lipschitz, Wu Shu, Joe Sicilian, Geneviève Verdier, and Jianbo Zhang for helpful comments.

${ }^{2}$ The International Monetary Fund, Said Business School, Oxford, and the London School of Economics, respectively.
} 


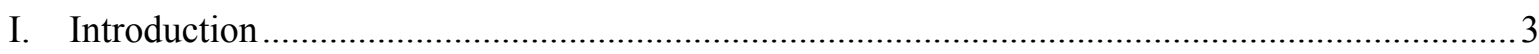

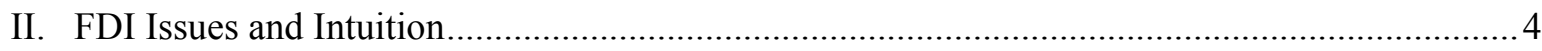

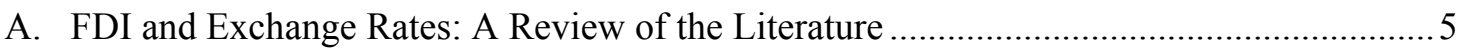

B. Evidence in Favor of Export-Platform FDI ............................................................... 6

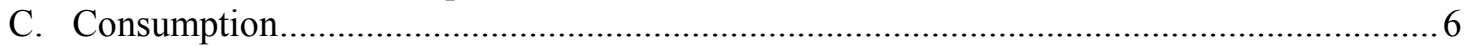

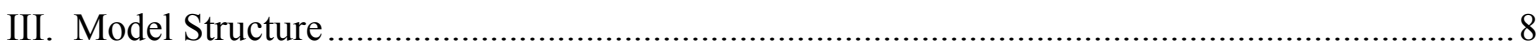

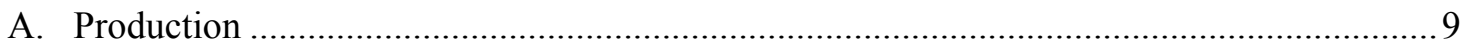

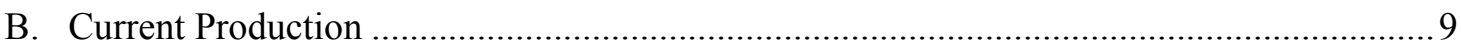

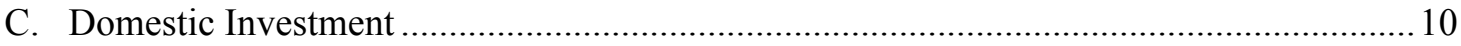

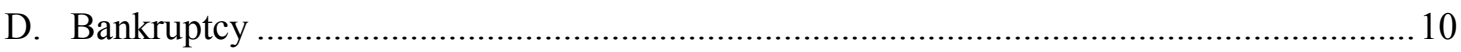

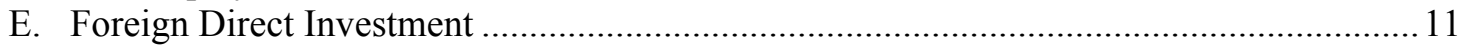

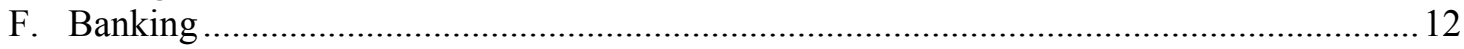

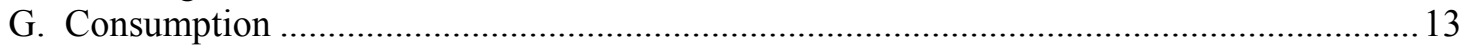

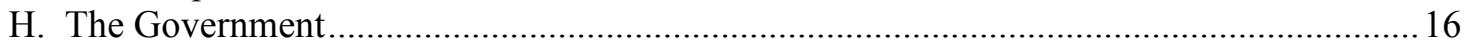

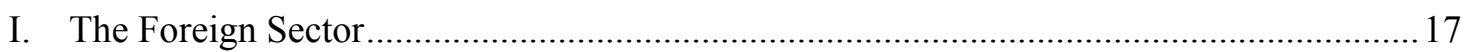

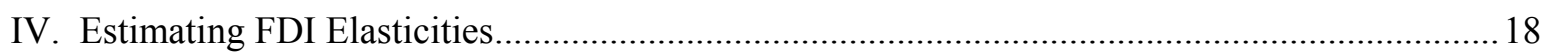

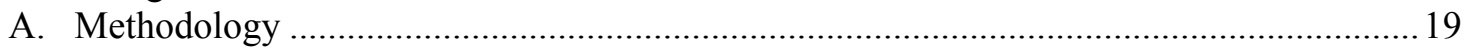

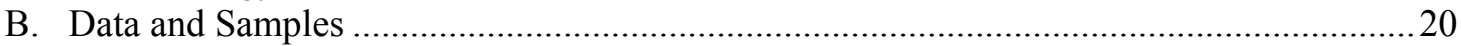

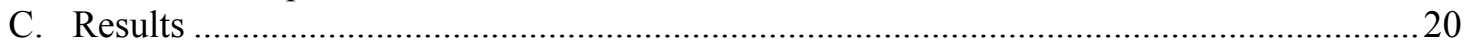

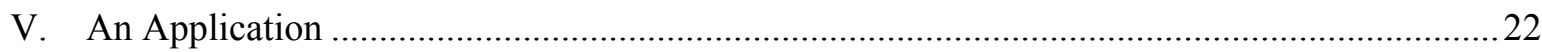

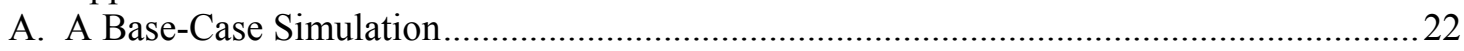

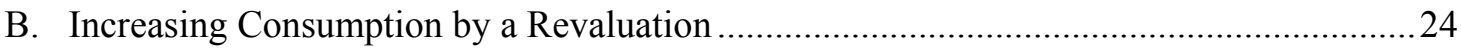

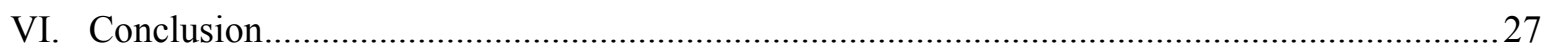

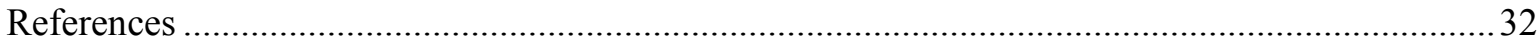

Tables

1. Elasticities of Changes in FDI Inflows with Respect to Real Interest Rates, Growth

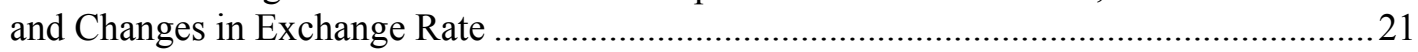

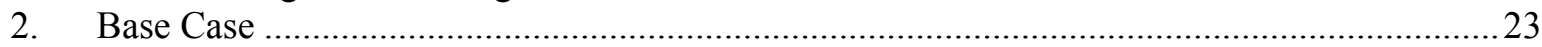

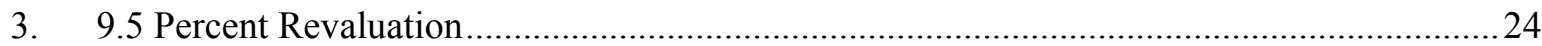

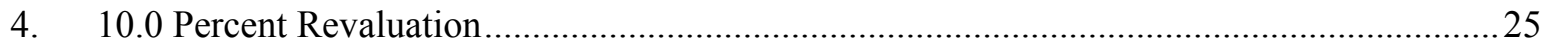

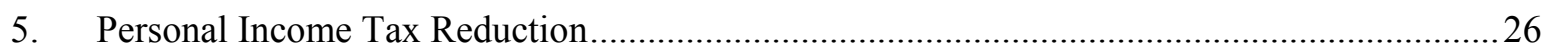

Figure 1. Real GDP Series Following a Tax Cut (\% Change Relative the Base Case)..................27

Appendix

Table 1. Consumption by Region and Source as a Share of GDP............................................29

Table 2. Gross National Savings and Investment as a Share of GDP .........................................29

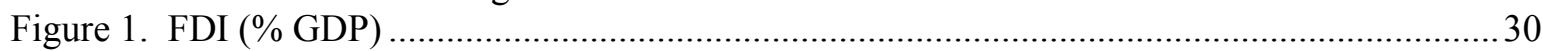

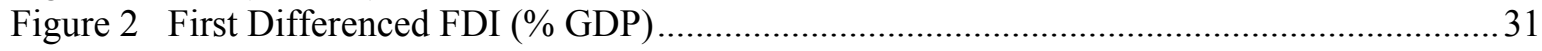




\section{INTRODUCTION}

This paper develops a model for the analysis of certain policy instruments that have been used to stimulate growth and consumption in a variety of economies. These instruments are often introduced in response to existing market distortions and their potentially adverse consequences. Thus, for example, an under-valued fixed exchange rate may have been used as a way to achieve high savings and investment rates. Similarly, high rates of return on capital caused by surplus labor, as well as the under-valued exchange rate, may attract foreign direct investment (FDI). Existing investors may then suffer unanticipated losses on their investments, as the return to capital falls. These losses, and resulting inability to service debt, may result in bank failures.

A key issue for a number of countries, especially in East Asia, is thus how to maintain high growth rates while avoiding the sort of financial collapse that occurred in 1997/98. Thus, for example, a country might wish to increase consumption in order to avoid the investment boom that can lead to financial pressures and possible bank failures. ${ }^{3}$

Focussing on domestic consumption is high on the policy priority list, most notably in China. In late 2004 the government formally endorsed a shift in the country's growth strategy from investment and export-led development towards one relying more on domestic consumption. ${ }^{4}$ The decision might reflect the perception that China's current growth model, based on ever faster growing investment and trade surplus, is not sustainable in the long run.

There are several underlying factors that might render the existing growth model unsustainable. To begin with, Chinese household consumption as a share of GDP has been falling rapidly in the recent years. In 2005 it accounted for only 38 percent of GDP compared to, for instance, 70 percent in the US or 61 percent in India. Furthermore, as it was recently acknowledged by the People's Bank of China, relying primarily on export growth intensifies the protectionist backlash in the US and other major Chinese export markets. ${ }^{5}$ Finally, and very closely related to our paper, excess investment in some sectors will lead to excess capacity and falling prices which could in turn create large non-performing loans, eroding the substantial recent balance sheet

\footnotetext{
${ }^{3}$ China is currently attempting to increase household consumption, largely by using domestic fiscal instruments. A revaluation of the exchange rate is not considered to be an immediate policy instrument.

${ }^{4}$ This issue was discussed in Central Economic Work Conference in Beijing in December 2004. Premier Wen Jiaobao re-iterated this policy in his "Report on the Work of the Government" to the National People's Congress in the spring of 2006 .

5 In its Report on the Implementation of Monetary Policy 2005Q2, the People's Bank of China admits that an excessive trade surplus "will escalate trade frictions" (People's Bank of China, Monetary Policy Analysis Small Group 2005, 28).
} 
improvements of the banks. The National Development and Reform Commission in its 2006 report to the National People's Congress alluded to this as a potential risk for the banks. ${ }^{6}$

Given the policy concerns above, how should the country increase consumption, yet avoid possible related macro economic difficulties? For example, a currency revaluation might increase consumption by making imports cheaper, but at the same time it could raise real interest rates, thereby limiting the ability of domestic investors to service their debts. A decrease in the personal income tax could bring about a reduction in work effort and increased consumption of leisure, thereby lowering the return to capital and again making debt repayment difficult.

The aim of this paper will be to analyze the welfare implications of alternative paths to the goals of increased consumption and financial stability. We develop a model that incorporates endogenous FDI that is a function of domestic growth, as well as domestic and foreign interest rate differentials. We will first see how the model can generate rapid growth, in response to stylized economic policies. We will then look at fiscal and exchange rate policies that can be used to achieve increased levels of private consumption, while maintaining high growth rates and avoiding financial collapse.

We will develop numerical applications of our model using certain stylized data. This data is derived from China, as well as a cross section of other East Asian countries. These applications should serve to illustrate potential outcomes and uses of our model, which cannot be solved analytically. We would not claim that the simulations have any immediate policy relevance for the countries whose data we use. Rather, these countries reflect the type of high growth situations in which we are interested, and serve as a useful focus for analysis. In the next section we will carry out a brief overview of our treatment of FDI for this model. Section III will develop the theoretical structure of the model. Section IV will discuss the data sources and parameter estimates that we will use in the calibration of the model. Section V will give examples of numerical simulations of the model, indicating how rapid growth policies may lead to financial failures. We will then carry out welfare analysis of different policies designed to increase consumption.

\section{FDI IsSUES AND INTUITION}

In this section, we will discuss two central ideas in our model and summarize the literature's view on these issues. The first issue concerns the effect of exchange rate movements on FDI, particularly through the competitiveness of the export sector (export-platform FDI). We will then discuss the implications of policies that boost domestic demand for FDI flows in the context of our general equilibrium model.

\footnotetext{
6 "Adverse effects of surplus production capacity in some industries have begun to emerge. Prices for the products of these industries dropped and inventories grew, corporate profits shrank and losses mounted, and potential financial risk has increased."
} 


\section{A. FDI and Exchange Rates: A Review of the Literature}

There are relatively few papers in the literature on FDI determinants that consider how changes in exchange rates might affect export-platform FDI. ${ }^{7}$ This is the channel implicitly assumed in our model. The mechanism we suggest is the following: Imagine a firm whose networth, or expected future stream of income flows, is affected by the exchange rate. Hence, the rate of return on capital in such a firm also changes with exchange rate movements, which in turn affects the level of investment in the firm, whether foreign or domestic. A typical example is the export industry. As domestic exchange rates appreciate, exports become less competitive compared to their foreign equivalents, reducing the expected future stream of income of the firm that produces them. We would therefore expect investment in this industry to go down.

The empirical literature on FDI has made considerable progress in explaining the patterns observed in the data, nevertheless without firm theoretical basis. The majority of these studies examine the determinants of FDI destination by firms, both at regional (within a country) and country level using reduced form regressions. Among these determinants, the most common are the market-size of the recipient region or country, regulations (such as taxation laws and trade barriers), institutions (such as legal protection of assets, corruption, well-functioning markets and infrastructure) and exchange rates. Our focus will generally be on exchange rates. ${ }^{8}$

One of the first papers to study this relationship is Froot and Stein (1991) who present a model with imperfect capital markets, in the sense that the internal cost of capital is lower than borrowing from external sources. Thus, an appreciation of home currency leads to an increase in firm wealth and provides the firm with greater internal funds for investment relative to rival firms in the foreign country that have experienced the devaluation of their currency. Thus, following a depreciation in its currency, a country will receive more FDI. The authors provide empirical evidence for their claim using inward FDI data for the US.

Blonigen (1997) suggests an alternative mechanism for the same result. He notes that FDI by a firm involves acquiring assets that are transferable within the firm and across markets, without a currency transaction (such as firm specific technology, managerial skills, etc.). Thus, a depreciation of the home currency will make these assets cheaper for foreign firms while leaving their nominal return unchanged (since after acquisition these assets can be transferred abroad at no cost and yield revenues in home currency). In other words, a depreciation of a country's currency will induce a "fire sale" of such transferable assets to foreign firms operating in global markets, versus domestic firms that may not have such access. Blonigen uses industry-level data on Japanese mergers and acquisition FDI into the US to test this hypothesis. He finds strong support for the existence of increased inward US FDI by Japanese firms in response to real dollar depreciations relative to the

\footnotetext{
${ }^{7}$ Export-platform FDI is generally defined as investment and production in a host country where the output is largely sold in third markets, not the parent or host-country markets.

${ }^{8}$ For a review of these empirical studies, see Blonigen (2005). Also see Fung, et. al. (2002), Leonard and Kwan (1998) and Lane \& Schmukler (2006) for determinants of FDI in China.
} 
yen. From a more macroeconomic perspective, Eichengreen and Tong (2005) cite anecdotal evidence that the depreciation of East Asian exchange rates encouraged fire-sale FDI.

\section{B. Evidence in Favor of Export-Platform FDI}

There is strong evidence in favor of export-platform FDI in East Asian and Latin American economies, and particularly in China. ${ }^{9}$ According to Whalley and Xin (2006), Foreign Invested Enterprises (FIEs) account for over 50 percent of exports from and 60 percent of imports into China; although they employ only 3 percent of the workforce. ${ }^{10}$ According to Hanson, Mataloni and Slaughter (2001), when compared to FDI into OECD and Latin America, the exports-to-sales ratio of FIEs in East Asia is the highest. Their data, which covers a period up to 1998, shows that in East Asia 50 percent of sales of FIEs are exported to third countries. This figure was 40 percent for Mexico and 30 percent for the rest of Latin America.

It is likely that the competitiveness of the export sector could be a major explanatory factor for the co-movements we observe between FDI flows and exchange rates. In summary, the literature has derived some important firm-level models of how exchange rate levels or volatility can affect FDI flows, but there is little work to assess the policy relevance of any of these theories.

\section{Consumption}

The second issue we would like to consider is the effect of increasing consumption on capital flows. An increase in consumption will cause interest rates to rise, since for the same level of output households now invest less. Higher interest rates imply lower asset prices, which tend to attract FDI. This effect is unambiguous. Consider now a simple thought experiment in which nominal exchange rates are revalued. Thus the foreign currency price of domestic assets increases. However, a revalued currency also increases consumption by households because their purchasing power has increased. Increased consumption, as explained above, will tend to increase FDI through lower asset prices. Therefore, the overall effect of a revaluation policy on FDI flows is ambiguous.

It is interesting to see whether such policies are also advocated in reality and if so, what they have achieved. There is an ongoing debate in the literature about the appropriate policy tools to "correct" global imbalances. Proposed policies include those aimed at boosting consumption, including revaluations of the exchange rate. This is consistent with our story, although we maintain that the effect of a nominal revaluation on the direction of net capital flows is ambiguous. ${ }^{11}$

\footnotetext{
${ }^{9}$ Eckholm, Forslid, and Markusen (2003), and Bergstrand and Egger (2004) develop models which rationalize why firms might engage in export-platform FDI. Markusen and Maskus (1999) test the predictions of existing models for the prevalence of export-platform FDI.

${ }^{10}$ See also Zhang and Song (2000).

${ }^{11}$ In this paper, we will not discuss the relative importance of the two counteracting channels affecting capital flows following a revaluation.
} 
We mentioned already the intention of the Chinese government to shift spending from investment to social spending and to oversee "an increased role for private consumption" (Kuijs, 2005). The IMF's view, as stated in its Asia Pacific Regional Economic Outlook (2006), is that raising private consumption in emerging Asia plays a crucial role both for achieving sustainable growth in the region and for reducing the global imbalances, as observed through a comparison of current account figures across countries. ${ }^{12}$

A few stylized facts about consumption patterns in East Asia are important to note here. By most accounts, consumption as a share of GDP in East Asia is low compared to other regions (see Tables 1 and 2 in the appendix). Also, these ratios have been stagnant (or decreasing in the case of China) during the past decade despite rising incomes in the region. Finally, demographics play an important role in this trend, so that even without any countervailing government policies, the consumption share is set to rise as populations in the region age and begin to dissave.

The dominant view is that there was a surge in precautionary savings following the Asian crisis, which has held back consumption even though incomes have risen dramatically. The absence of social safety nets, under-developed financial markets that enable households to diversify risks, and a large proportion of the population saving heavily as they approach retirement age, have contributed to this precautionary measure.

A recent study by the IMF examines this common perception. ${ }^{13}$ Pre-crisis consumption levels, given economic fundamentals, are used to form out-of-sample forecasts for consumption levels after the crisis. The study finds that private consumption in East Asia recovered after the crisis, and in many cases exceeded the out-of-sample forecast. This offers evidence that precautionary saving declined as populations grew more confident about subsequent growth. The one case where the private consumption-to-GDP ratio is consistently below the out-of-sample forecast is China. The report concludes that precautionary savings in China may have risen permanently in the wake of the Asian crisis.

Overall, there seems to be a consensus, at least in policy circles, on the fact that consumption in East Asia is low by international standards. There also appears to be agreement on how to remedy the consequences of this fact - by shifting government expenditure from investment to consumption to speed up the transition to a sustainable equilibrium.

This paper offers a more rigorous evaluation of such policy recommendations. The policy advice has generally recommended an increase in government consumption expenditure, such as social safety nets, health care, and education. Here we will consider direct government transfers such as tax-cuts, which are generally simpler to implement in practice, and which should have similar welfare implications.

\footnotetext{
12 The latter point has often been emphasized by the IMF in different forums; e.g. see World Economic Outlook (2005).

13 Asia-Pacific Regional Economic Outlook, 2006.
} 


\section{Model Structure}

In this section we will develop the analytical structure of our model, which is related to Ball and Feltenstein (2001) and Blejer, Feldman, and Feltenstein (2002). Much of this structure is designed in order to permit a numerical implementation, as well as to permit welfare analysis with heterogeneous agents. Our model has $n$ discrete time periods. All agents optimize in each period over a 2 period time horizon. That is, in period t they optimize given prices for periods $t$ and $t+1$ and expectations for prices for the future after $t+1$. When period $t+2$ arrives, agents re-optimize for period $t+2$ and $t+3$, based on new information about period $t+2$. Thus the savings decision made in period $t+1$ may not give an optimal allocation when period $t+2$ arrives.

We thus have a system in which expectations are consistent for 2 periods and then may be inconsistent thereafter. Updating takes place and expectations are again consistent for 2 periods and inconsistent thereafter. We adopt this framework for an essentially technical reasons. We wish to avoid having a perfect foresight model since it would not be possible to generate insolvencies in such a model. We have a particular interest in insolvencies that are caused by domestic investors incorrectly forecasting the growth in FDI, thereby overestimating the return to their own investments. Of course such an incorrect forecast would be impossible in a perfect foresight framework.

There are alternative modeling strategies to our imperfect foresight assumption that might also be used to generate crises. A stochastic model with perfect foresight rational expectations would also deliver the similar insights, at the cost of considerable additional complexity. A second alternative would be to allow for different states of the world, for example, differences in government policy or different potential types of foreign investors. If domestic agents only have information about the probability distribution of these different states of the world, it would also be possible to generate crises. We believe that for the purposes of our model, these alternative modeling techniques are not fundamentally different. In other words, they are alternative representations of a world in which agents have imperfect information about the future. We choose the imperfect foresight representation over the others purely for modeling convenience.

Our model structure is related to a number of earlier papers, possibly starting with Strotz (1956). Here preferences are inconsistent over time, primarily because the future does not turn out as anticipated. Thus it may be optimal for agents to commit themselves for a few periods into the future. They may be better off, however, if they re-optimize at some later date, based on their own changed preferences or changes in economic variables. This is quite different from the notion of time inconsistency of Kydland and Prescott (1977), where rational behavior by economic agents itself leads to inconsistencies in what would otherwise be an optimal government plan. 


\section{A. Production}

There are 8 factors of production and 3 types of financial assets:
1-5. Capital types
9. Foreign currency
6. Urban labor
10. Rural labor
7. Domestic currency
11. Land
8. Bank deposits

The five types of capital correspond to five aggregate non-agricultural productive sectors. We could have any number of capital types without affecting the structure of the model, our choice of five is essentially arbitrary. ${ }^{14}$ Each of these factors and financial assets is replicated in each period and, accordingly, has a price in each period. Period 1 domestic currency is the numeraire.

\section{B. Current Production}

An input-output matrix, $A_{t}$, is used to determine intermediate and final production in period t. Corresponding to each sector in the input-output matrix, sector specific value added is produced using capital and urban labor for the non-agricultural sectors, and land and rural labor in agriculture. The different factors are allocated across the economy so that agriculture uses land and rural labor, and all other sectors use one of the five capital types plus urban labor. Accordingly, capital is perfectly mobile across a given sub-sector, but is immobile across other sub-sectors. Labor, on the other hand, may migrate from the rural to the urban sector.

The specific formulation of the firm's problem is as follows. Let $y_{K i j}, y_{L i j}$ be the inputs of capital and urban labor to the jth non-agricultural sector in period i. Let $Y_{G i}$ be the outstanding stock of government infrastructure in period $\mathrm{i}$. The production of value added in sector $\mathrm{j}$ in period $\mathrm{i}$ is then given by:

$$
v a_{i j}=v a_{i j}\left(y_{K i j}, y_{L i j}, Y_{G i}\right)
$$

where we suppose that public infrastructure may act as a productivity increment to private production.

Sector $\mathrm{j}$ pays income taxes on inputs of capital and labor, given by $t_{K i j}, t_{L i j}$, respectively, in period i. Agriculture is taxed on its use of labor. Hence the effective price for labor and capital paid by sector $\mathrm{j}$ is:

$$
\tilde{P}_{L i j}=\left(1+t_{L i j}\right) P_{L i}, \tilde{P}_{K i j}=\left(1+t_{K i j}\right) P_{K i j}
$$

\footnotetext{
${ }^{14} \mathrm{We}$ wish to avoid using a single, perfectly mobile, capital type since it would generate overly rapid sectoral adjustments. Also, this number of capital types corresponds to our available data sets.
} 
Thus if $\tilde{P}_{K i j}, \tilde{P}_{L i j}$ are the prices of capital and labor in period i, then the prices charged by enterprises, $P_{i}$, are given by

$$
P_{i}=v a\left(P, Y_{G i}\right)(1+t)(I-A)^{-1}
$$

where $v a\left(P, Y_{G i}\right)$ is the vector of cost-minimizing value-added per unit of output.

\section{Domestic Investment}

We suppose that domestic investors produce each type of sectoral capital via a sector-specific investment technology that uses inputs of capital and labor to produce new capital. Domestic investment is carried out by the private sector and is entirely financed by domestic borrowing in the home currency. Let us define the following notation.

$t_{K i}=$ Profit (capital) tax rate (percent)

$C_{H i}=$ The cost of producing the quantity $H$ of capital in period $\mathrm{i}$.

$r_{i}=$ The interest rate in period $i$.

$P_{K i}=$ The return to capital in period i.

$P_{M i}=$ The price of money in period i.

$\delta=$ The rate of depreciation of capital.

Suppose, then, that the rental price of capital in period 1, or whatever the current period might be, is $P_{1}$. The cost of borrowing must equal the present value of the return on new capital. Hence:

$$
C_{H I}=\sum_{i=2}^{N}\left[\frac{\left(1-t_{K i}\right) P_{K i}(1-\delta)^{i-2} H_{1}}{\prod_{j=1}^{i-1}\left(1+r_{j}\right)}\right]
$$

where $r_{j}$ is the interest rate in period $\mathrm{j}$, given by:

$$
r_{j}=1 / P_{B j}
$$

and $P_{B j}$ is the price of a bond in period j. Accordingly, the investor takes out a loan from the banking system to cover his costs. This loan then becomes an asset of the banking system.

\section{Bankruptcy}

We make one further assumption about the behavior of the individual firm. The firm, like all other agents in the model, optimizes with a 2 period time horizon for which it knows all prices. 
After the second period it assumes that future interest rates and returns to capital will remain the same as in period 2. Hence $P_{K i}=P_{K 2}, r_{i}=r_{2} ; i>2$. If at some point the present value of investment, as given in equation (3), falls below the corresponding value of debt service, then the sector is unable to pay its debt obligations which were incurred to finance this investment.

Accordingly, the bank which holds these assets now holds corresponding bad debts. This situation might occur if, after the investment was incurred, the interest rate rose or the rate of return to capital fell, due to some unanticipated event. We assume that a bankrupt firm cannot invest.

\section{E. Foreign Direct Investment}

We model the foreign investor in an, admittedly, ad hoc way based upon the empirical estimates described in the next section. The foreign investor, considering direct capital investment in the home country, looks at 3 endogenous variables. These are the past (most recent) rate of growth in real GDP in the country, the current relative nominal interest rates in the home country and the rest of the world (the US interest rate), and the expected change in the home country's exchange rate (against the US \$). Thus we would expect that the change in FDI would be given by:

$$
\Delta F D I_{i}=\alpha E\left(\frac{e_{i+1}}{e_{i}} \frac{r_{i}}{r_{F i}}-1.0\right)+\beta \Delta G D P_{d o m}
$$

Here $e_{i}$ denotes the exchange rate in period $i$ while $r_{F i}$ denotes the foreign (US \$) interest rate. $G D P_{d o m}$ is the home country's GDP.

Thus if domestic interest rates are higher than foreign rates, then domestic asset prices will be lower than foreign asset prices, leading to an increase in FDI. Similarly, if a depreciation of the exchange rate is expected, then a decline in domestic asset prices is also expected. Hence we expect that $\alpha$ should be positive. The second term on the RHS is the domestic growth rate. The next section will show that, for the set of countries on which our analysis is based, this is also positively related to changes in FDI. Accordingly, $\boldsymbol{\beta}$ should also be positive.

FDI is allocated across sectors according to the existing share of the nominal value of sectoral capital in total nominal capital. Thus let $W_{K i j}$ denote the total stock of capital of type $\mathrm{j}$ at the beginning of period i. Let $K R A T I O_{i j}$ represent the share of the nominal value of capital of type $\mathrm{j}$ in period $i$ in the total nominal value of the existing capital stock, given by:

$$
K R A T I O_{i j}=\frac{P_{K i j} W_{K i j}}{\sum_{1}^{K} p_{K i j} W_{K i j}}
$$


Then nominal FDI going to sector $\mathrm{j}$ in period $\mathrm{i}$ is given by:

$$
F D I_{i j}=K R A T I O_{i j} *\left(1+\Delta F D I_{i}\right) * F D I_{i-1}
$$

Thus FDI "follows" prior capital formation in the sense that it is allocated according to existing shares of nominal capital. Clearly this does not reflect optimizing behavior on the part of foreign investors, who are following the investment decisions made by optimizing domestic investors, who have allocated past investments based on sectoral rates of return. Nonetheless, we believe that it is possible to justify this modeling approach by claiming that observed behavior of domestic investors may represent the best available information to the foreign investor.

\section{F. Banking}

The banking sector in our model is quite simple. We will suppose that there is at least one bank for each non-agricultural sector of the economy. Each bank lends primarily to the sector with which it is associated. The banks are, however, not fully specialized in the sector to which they correspond. We will make the simplifying assumption that each bank holds 50 percent of the outstanding debt of its particular sector. It then holds the remainder of its assets uniformly distributed across each of the remaining sectors in the economy. Suppose, for example, that there are 5 sectors. In this case bank 3, for example, holds 50 percent of the debt of sector 3, and 12.5 percent of the remainder of its assets are in each of sectors $1,2,4$, and 5. We make this assumption of diversification of assets in order to avoid a possible situation in which the insolvency of a particular sector leads to the automatic insolvency of its related bank.

We will suppose that banks follow a strategy of lending that looks at the risks associated with their borrowers. That is, as their borrowers become more insolvent, the banks ration credit to those borrowers. ${ }^{15}$ We will choose a simple functional form that connects credit rationing to borrower insolvency. Suppose that $C_{H i j}$ is the demand for borrowing by sector $\mathrm{j}$ in period i. Suppose also that bank $\mathrm{k}$ has $D E F_{i k}$ percent of its total assets in default in period i. Let $\delta_{k} \succeq 0$ be a parameter specific to bank $\mathrm{k}$, and let $\boldsymbol{\beta}_{j k}$ be the share of borrowing by sector $\mathrm{j}$ taken by bank $\mathrm{k}$. Sector $\mathrm{j}$ then receives loans $L_{j i}$ where:

$$
L_{i j}=\sum_{k=1}^{N} \beta_{j k}\left(1-\delta_{k} D E F_{i k}\right) C_{H i j}
$$

Thus if there are no bank assets in default, then no credit rationing takes place. If assets are in default, then the credit demanded by sector $\mathrm{j}$ for investment is reduced by each bank proportionally to the share of that bank's defaulted assets in total assets. The parameter $\delta_{k}$ is a measure of the risk

\footnotetext{
15 Our approach is a simple version of that presented in Calormiris and Wilson (1998).
} 
aversion of banks. Higher values of $\delta_{k}$ indicate a more rapid contraction of credit in response to bad loans. We impose a solvency requirement on the banking system. Namely, if $\alpha$ percent of a bank's assets are in default, caused by a corresponding insolvency in its borrowers, then the bank is declared insolvent. At this point a fraction of the bank's deposits are seized by the government. ${ }^{16}$ In particular, depositors in the bank find part of their deposits frozen. We use a simple rule to determine the fraction of a bank's deposits that are seized. If $D E F_{i k}$ is the share of bank k's assets that are in default in period $i$, as before, then regulators seize $\omega_{k} D E F_{i k}$ of the bank's deposits, where $\omega_{k}$ is a bank specific parameter. This seizure of deposits correspondingly reduces the bank's ability to lend. Thus the bank's supply of loans, and hence its assets, are determined by the demand for loans from the productive sectors of the economy, as well as the risk imputed to potential borrowers

\section{G. Consumption}

There are two types of consumers, representing rural and urban labor. We suppose that the two consumer classes have differing Cobb-Douglas demands. The consumers also differ in their initial allocations of factors and financial assets. The consumers maximize intertemporal utility functions, which have as arguments the levels of consumption and leisure in each of the two periods, subject to intertemporal budget constraints. The consumer saves by holding money, domestic bank deposits, and foreign currency. He requires money for transactions purposes, but his demand for money is sensitive to the interest rate. In addition, the consumer's demand for bank deposits is sensitive to his perception of the solvency of the banking system. In particular, as banks increasingly incur bad loans, the consumer's interest elasticity of money declines, causing him to reduce his bank deposits. ${ }^{17}$

In order to avoid unreadable subscripts, let 1 refer to period $i$ and 2 refer to period $i+1$. The consumer's maximization problem is then:

$\max U(x), \quad x=\left(x_{1}, x_{L u 1}, x_{L r 1}, x_{2}, x_{L u 2}, x_{L r 2}\right)$

such that:

$$
\left(1+t_{i}\right) P_{t} x_{i}+P_{L u i} x_{L u i}+P_{L r i} x_{L r i}+P_{M i} x_{M i}+P_{B i} x_{B i}+e_{i} P_{B F i} x_{B F i}=C_{i}
$$

\footnotetext{
${ }^{16} \mathrm{We}$ are reproducing standard bank regulations. That is, if the average ratio of capital to total assets in the banking system is approximately $\alpha$ percent, then an $\alpha$ percent loss of assets would be tantamount to a total loss of capital. In practice, a figure of 8 percent in generally used by regulators in the United States.

${ }^{17}$ This reflects the notion that the consumer worries about the safety of his own deposits as he sees the banks become progressively more insolvent.
} 


$$
\begin{gathered}
P_{K 1} K_{0}+P_{A 1} A_{0}+P_{L u 1} L_{u 1}+P_{L r 1} L_{r 1}+P_{M 1} M_{0}+r_{0} B_{0}+P_{B 1} B_{0}+e_{1} P_{B F 1} B_{F 0}+T R_{1}=N_{1} \\
P_{K 2}(1-\delta) K_{0}+P_{A 2} A_{0}+P_{L u 2} L_{u 2}+P_{L r 2} L_{r 2}+P_{M 2} x_{M 1}+r_{1} x_{B 1}+P_{B 2} x_{B 1}+e_{2} P_{B F 2} x_{B F 1}+T R_{2}=N_{2} \\
C_{i}=N_{i}
\end{gathered}
$$

$$
\begin{gathered}
\log P_{B i} x_{B i}-\log e_{i} P_{B F t} x_{B F i}=\alpha+\beta\left(\log r_{i}-\log \frac{e_{i+1}}{e_{i}} r_{F i}\right) \\
\log \left(L_{u l} / L_{r i}\right)=a_{1}+a_{2} \log \frac{P_{L u i}-P_{L r i}}{P_{L u i}+P_{L r i}}
\end{gathered}
$$

$\log P_{M i} x_{M i}=a+b \log \left(1+t_{i}\right) P_{i} x_{i}-c \log \pi_{i} ; c=c(D E F / A S S E T)$

$$
P_{B 2} x_{B 2}=d_{0}+d_{1}\left(1+t_{2}\right) P_{2} x_{2}+d_{2}\left[\frac{r_{2}-\pi_{2}}{1+\pi_{2}}\right]
$$

where:

$P_{i}=$ price vector of consumption goods in period $\mathrm{i}$.

$x_{i}=$ vector of consumption in period i.

$C_{i}=$ value of aggregate consumption in period i (including purchases of financial assets).

$N_{i}=$ aggregate income in period i .

$t_{i}=$ vector of sales tax rates in period $\mathrm{i}$.

$P_{L u i}=$ price of urban labor in period i. 
$a_{2}=$ elasticity of rural/urban migration.

$P_{k i}=$ price of capital in period i.

$K_{0}=$ initial holding of capital.

$P_{A i}=$ price of land in period $\mathrm{i}$.

$A_{0}=$ initial holding of land.

$\delta=$ rate of depreciation of capital.

$P_{M i}=$ price of money in period $\mathrm{i}$.

$x_{M i}=$ holdings of money in period $\mathrm{i}$.

$P_{B i}=$ discount price of a certificate of deposit in period $i$.

$\pi_{i}=$ domestic rate of inflation in period $i$.

$r_{i}, r_{F i}=$ the domestic and foreign interest rates in period $\mathrm{i}$.

$e_{i}=$ exchange rate in terms of units of domestic currency per unit of foreign currency in period $i$.

$T R_{i}=$ transfer payments from the government in period $\mathrm{i}$.

$a, b, \alpha, \beta=$ estimated constants.

$d_{i}=$ constants estimated from model simulations.

$D E F=$ The value of non-performing assets in the banking system.

$A S S E T=$ Total assets of the banking system.

$c=$ a functional form that depends negatively upon the ratio of non-performing assets to total assets in the banking system.

The left hand side of equation (5a) represents the value of consumption of goods and leisure, as well as of financial assets. The next two equations contain the value of the consumer's holdings of capital and labor, as well as the principal and interest that he receives from the domestic and foreign financial assets that he held at the end of the previous period. The equation $C_{i}=N_{i}$ then imposes a budget constraint in each period. Equation (5d) is a standard money demand equation in which the demand for cash balances depends upon the domestic rate of inflation and the value of intended consumption. There is, however, one modification. The inflation elasticity, $\mathrm{c}$, is inversely related to the share of non-performing bank assets in total assets. As non-performing assets rise, c declines.

Equation (5b) says that the proportion of savings made up of domestic and foreign interest bearing assets depends upon relative domestic and foreign interest rates, deflated by the change in the exchange rate. Finally, equation (5c) is a migration equation that says that the change in the consumer's relative holdings of urban and rural labor depends on the relative wage rates. 
In period 2 we impose a savings rate based on adaptive expectations, as in equation (5e). The constants $\left(d_{i}\right)$ are estimated by a simple regression analysis, based on the previous periods. The constants are updated after each two period segment by running a regression on the previous $t-2$ periods. Thus savings rates are endogenously determined by intertemporal maximization in period $t$, but are determined by adaptive expectations in period $t+1 .^{18}$

When period $t+2$ begins, the consumer's holdings of financial assets may be different than those incorporated in the above problem, since defaults may have occurred. The consumer then optimizes again for periods $t+2, t+3$, based on his new, unexpected holdings of financial assets at the beginning of period $t+2$.

\section{H. The Government}

The government collects personal income, corporate profit, and value added taxes, as well as import duties. It pays for the production of public goods, as well as for subsidies. In addition, the government must cover both domestic and foreign interest obligations on public debt. The deficit of the central government in period $1, \mathrm{D}_{1}$, is then given by:

$$
D_{1}=G_{1}+S_{1}+r_{1} B_{0}+r_{F I} e_{1} B_{F 0}-T_{1}
$$

where $S_{1}$ represents subsidies given in period $1, G_{1}$ is spending on goods and services, while the next two terms reflect domestic and foreign interest obligations of the government, based on its initial stocks of debt. $\mathrm{T}_{1}$ represents tax revenues.

The resulting deficit is financed by a combination of monetary expansion, as well as domestic and foreign borrowing. If $\Delta \mathrm{y}_{\mathrm{BG} 1}$ represents the face value of domestic bonds sold by the government in period 1 , and $\mathrm{C}_{\mathrm{F} 1}$ represents the dollar value of its foreign borrowing, then its budget deficit in period 2 is given by:

$$
D_{2}=G_{2}+S_{2}+r_{2}\left(\Delta y_{B G 1}+B_{0}\right)+e_{2} r_{F 2}\left(C_{F 1}+B_{F 0}\right)-T_{2}
$$

where $r_{2}\left(\Delta y_{B G 1}+B_{0}\right)$ represents the interest obligations on the initial domestic debt plus borrowing from period 1 , and $e_{2} r_{F 2}\left(C_{F 1}+B_{0}\right)$ is the interest payment on the initial stock of foreign debt plus period 1 foreign borrowing.

\footnotetext{
${ }^{18}$ Since the only information the consumer has about the future is the real interest rate, adaptive expectations are, in this case, equivalent to rational expectations.
} 
The government finances its budget deficit by a combination of monetization, domestic borrowing, and foreign borrowing. We assume that foreign borrowing in period i, $C_{F i}$, is exogenously determined by the lender.

\section{The Foreign Sector}

The foreign sector is represented by a simple export equation in which aggregate demand for exports is determined by domestic and foreign price indices, as well as world income. The specific form of the export equation is:

$$
\Delta X_{n o}=\sigma_{1}\left[\frac{\pi_{1}}{\Delta e_{i}+\pi_{F i}}\right]+\sigma_{2} \Delta y_{w i}
$$

where the left hand side of the equation represents the change in the dollar value of exports in period $i, \pi_{i}$ is inflation in the domestic price index, $\Delta e_{i}$ is the percentage change in the exchange rate, and $\pi_{F i}$ is the foreign rate of inflation. Also, $\Delta y_{w i}$ represents the percentage change in world income, denominated in dollars. Finally, $\sigma_{1}$ and $\sigma_{2}$ are corresponding elasticities.

The combination of the export equation and domestic supply responses then determines aggregate exports. Demand for imports is endogenous and is derived from the domestic consumers' maximization problems. Gross capital inflows are determined by FDI, from the previous section. The supply of foreign reserves $y_{F G i}$, available to the government in period $\mathrm{i}$ is given by:

$$
y_{F G i}=y_{F G(i-1)}+x_{F(i-1)}-x_{F i}+C_{F i}
$$

Here $x_{F i}$ represents the demand for foreign assets by citizens of the home country, so $x_{F(i-1)}-x_{F i}$ represents private capital flows. $C_{F i}$ represents exogenous foreign borrowing by the home government.

Finally changes in the money supply in period i, $\Delta M_{S i}$, are now given by:

$$
\Delta M_{S i}=\Delta y_{M i}+\Delta O M O_{i}+e_{i} y_{F G i}-e_{i-1} y_{F G(i-1)}
$$

where $\Delta y_{M i}$ is determined by the government's financing of its budget deficit, and $\triangle O M O_{i}$ represents money created via open market operations. The remainder of the right hand side represents the domestic currency value of the balance of payments. 


\section{Estimating FDI Elasticities}

In calibrating the model for our simulations, we have used the Chinese Statistical Yearbook (various issues) to obtain the IO matrix, as well as deriving indirect taxes and import tariff rates. The approach is described in Feltenstein and Nsouli (2003). In this section, we describe our estimation procedure for obtaining the FDI elasticities with respect to interest rates, growth and exchange rate movements, which we have used to endogenize FDI in our model(III.E).

These estimates are not readily available from previous work in the literature. As mentioned in Section II , most of the empirical studies on FDI have focused on the trend component of FDI flow. These studies identify factors that explain cross-country differences in FDI flows and often find institutional factors such as investor protection laws, depth of the financial sector, trade and capital account openness and the like, as important explanatory variables for FDI inflows.

For our purposes however, we need a relationship between FDI flows and other endogenous variables in order to close the model. This time-varying relationship should be regarded as explaining the deviations of FDI flows from trend, rather than the trend itself. The obvious candidates for determinants of these deviations are real interest rates differentials, expected depreciation and real growth.

Although we do not explicitly derive these relationships from a theoretical model, we do have some priors about the variables that might affect FDI flows and the signs of their elasticities. Uncovered interest parity (UIP) tells us that we should expect FDI to rise with rising differentials between home and foreign real interest rate adjusted by expected deflation. ${ }^{19}$ Thus, one obvious independent variable to considerwill be interest rate differentials, adjusted by expected devaluation. We also expect that FDI flows rise after a devaluation of the currency. The mechanism is the following: Most of the FDI flows from a developed to a developing economy are for investment in the export sector. Therefore, the lower the exchange rate, the more competitive the exporting industries become, as compared to their foreign rivals and the higher their expected future profitability. This higher profitability will attract more FDI.

For similar reasons, we expect higher GDP growth to have a positive impact on FDI flows as well. Probably the most significant channel for this effect is simple accounting: higher FDI each year will directly be counted as higher investment in national accounting data. However, conceivably there are more indirect effects at work too; to the extent that higher GDP growth indicates higher productivity of capital, it will attract more FDI flows. Furthermore, assuming that there is some serial correlation in growth rates, higher growth this year would mean higher expected growth for next year, which induced higher investment this year.

\footnotetext{
${ }^{19}$ Of course, for this flow to be finite, there must be some form of capital controls or increasing transaction costs. Again, we do not model these frictions.
} 


\section{A. Methodology}

In calibrating the IO matrices, we only used Chinese data as a very stylized example. To estimate the FDI flow elasticities however, we use a panel data set comprising of 11 countries in developing Asia. ${ }^{20}$ Although we are interested in finding the elasticities of FDI flows within a specific country, we believe using a panel was appropriate for a few reasons: First, from a practical point of view, unlike the case for IO matrices, there is not enough annual data on FDI available for any single country to obtain estimates with reasonable confidence intervals. Second, the model does not aim to explain the economic movements of a particular country. Furthermore, by using a fixed effect panel data model for our estimation, we have restricted our attention to variations of FDI with respect to macro variables of interest. We have specified our estimation equation as follows:

$$
\Delta F D I_{i t}=\alpha+\gamma_{i}+\beta_{1} * \text { growth }_{i t}+\beta_{2} * r_{i t}+\beta_{3} * \text { deval }_{i t}+\epsilon_{i t}
$$

The dependent variable, $\Delta F D I$, is measured as the change in the GDP share of FDI from the previous year. FDI (\%GDP) has been increasing rapidly over the last 2 decades, hence the data is highly non-stationary. The rate and the consistency of growth of FDI flows are not matched by the developments in any other macro economic indicator over the same period. Therefore, we first need to transform these series into a stationary measure. To do this, we use first differenced FDI as our dependent variable. As Figure 1 in the Appendix shows, the FDI series are clearly non-stationary both in East Asia and in OECD. This non-stationarity is almost entirely removed by first differencing the FDI series (Figure 2, Appendix).

The independent variables, GDP growth ( $\%$ annual), real interest rates ( $\%$ annual), and year-on-year average nominal devaluation (\%) are all stationary and therefore are used in the regressions in their original form. We also experimented with several other variables on the right hand side, including inflation, and lending rates, as well as lags and leads of growth and devaluation. However, only in the parsimonious specification above did we obtain beta coefficients that were statistically significant and robust to different estimation methods.

Given that FDI series are integrated of order 1, regressing FDI on lagged FDI values and independent variables will result in "super consistency" of estimates, though we know that in small samples, the coefficient is biased downwards and the estimated t- and F- values are incorrect. Therefore, we rule out this specification. We also rule out regressing FDI on a time dummy and other independent variables, since this specification will give rise to a spurious regression. That is,. the standard errors are very low simply because the FDI series is increasing over time (time variance dominates the variance in every other stationary variable on the right hand side).

\footnotetext{
${ }^{20}$ These countries are China, Hong Kong SAR, India, Indonesia, Republic of Korea, Macao SAR, Philippines, Singapore, Thailand and Vietnam.
} 
We used three main variations of the panel data model to estimate equation (8): First, we used a simple fixed effect regression with robust standard errors. In our second specification, we use a fixed effect model with first-order autoregressive disturbances. ${ }^{21}$ Finally, we use a feasible GLS model, which estimates the panel in the presence of AR(1) autocorrelation within panels and cross-sectional correlation and heteroskedasticity across panels. Specifically, we have assumed that, within panels there is AR(1) autocorrelation and that the coefficient of the AR(1) process differs across panels.

\section{B. Data and Samples}

We use data from three different country groups: Developing Asia, G20 $0^{22}$ and $\mathrm{OECD}^{23}$ for the period 1985-2005. Although we only use the estimates for the developing Asia in our simulations, the estimation for other country groups was carried out as a robustness check. We collected our data from the World Bank's World Development Indicators database (WDI). Some regressions also used data on FDI from UN Foreign Direct Investment database. The results are almost identical.

\section{Results}

The results are presented in Table 1. P-values are in parentheses below each point estimate. We are only presenting the elasticities with respect to devaluation (efd), real interest rates (efr) and growth (efg), as presented in the final form of our regression. Other variables including inflation, lending rates and different lags of independent variables were not associated with FDI flows in a statistically significant way and hence their elasticities are not presented here.

21 This model assumes the following set up:

$$
y_{i t}=\alpha+x_{i t}^{\prime} \beta+u_{i}+e_{i t}
$$

where

$$
e_{i t}=\rho e_{i t-1}+z_{i t}
$$

and where $|\rho|<1$ and $z_{i t}$ is independent and identically distributed (iid) with zero mean and variance.

22 Argentina, Brazil, Chile, China, Colombia, Czech Republic, Egypt, Hong Kong, Hungary, India, Indonesia, Israel, Jordan, Korea, Malaysia, Mexico, Morocco, Pakistan, Peru, Philippines, Poland, Russia, Saudi Arabia, Singapore, Slovak Republic, Slovenia, South Africa, Thailand and Turkey.

${ }^{23}$ Australia, Austria, Belgium, Canada, Czech Republic, Denmark, Finland, France, Germany, Greece, Hungary, Iceland, Ireland, Italy, Japan, Korea, Luxembourg, Mexico, Netherlands, New Zealand, Norway, Poland, Portugal, Slovak Republic, Spain, Sweden, Switzerland, Turkey, United Kingdom, United States. 
Table 1. Elasticities of Changes in FDI Inflows with Respect to

Real Interest Rates, Growth and Changes in Exchange Rate

\begin{tabular}{|c|c|c|c|c|c|c|c|c|c|}
\hline & \multicolumn{3}{|c|}{ East Asia } & \multicolumn{3}{|c|}{ OECD } & \multicolumn{3}{|c|}{ G20 } \\
\hline & (1) & (2) & (3) & (1) & (2) & (3) & (1) & (2) & (3) \\
\hline$e f r$ & $\begin{array}{c}0.162 * * \\
-0.02\end{array}$ & $\begin{array}{c}0.186^{* *} \\
-0.02\end{array}$ & $\begin{array}{c}0.145^{* *} \\
-0.02\end{array}$ & $\begin{array}{l}0.041 \\
-0.61\end{array}$ & $\begin{array}{l}0.038 \\
-0.68\end{array}$ & $\begin{array}{l}0.03 \\
-0.6\end{array}$ & $\begin{array}{l}0.012 \\
-0.41\end{array}$ & $\begin{array}{l}0.013 \\
0.577\end{array}$ & $\begin{array}{l}0.008 \\
-0.47\end{array}$ \\
\hline$e f g$ & $\begin{array}{c}0.198^{* * *} * \\
-0.01\end{array}$ & $\begin{array}{c}0.229^{* * * *} \\
0\end{array}$ & $\begin{array}{c}0.179^{* * *} \\
0\end{array}$ & $\begin{array}{c}0.213^{* *} \\
-0.05\end{array}$ & $\begin{array}{c}0.235^{* *} \\
-0.05\end{array}$ & $\begin{array}{l}0.117 \\
-0.15\end{array}$ & $\begin{array}{c}0.083^{* *} \\
-0.04\end{array}$ & $\begin{array}{c}0.102 * * \\
0.033\end{array}$ & $\begin{array}{c}0.062^{* *} \\
-0.04\end{array}$ \\
\hline efd & $\begin{array}{c}0.032 * \\
-0.06\end{array}$ & $\begin{array}{c}0.039 * * \\
-0.05\end{array}$ & $\begin{array}{l}0.027^{*} \\
-0.06\end{array}$ & $\begin{array}{c}-0.783 \\
-0.6\end{array}$ & $\begin{array}{c}-0.815 \\
-0.62\end{array}$ & $\begin{array}{l}-0.87 \\
-0.5\end{array}$ & $\begin{array}{c}0 \\
-0.56\end{array}$ & $\begin{array}{c}0 \\
0.623\end{array}$ & $\begin{array}{c}0 \\
-0.65\end{array}$ \\
\hline
\end{tabular}

(1) Simple FE(2) AR(1) (3) FGLS

There are a few interesting points to notice about our results: First, the point estimates using different estimation methods are very close for all elasticities in all three regions. Except for one case (the elasticity of changes in FDI flows with respect to growth in G20), we either reject or accept the statistical significance of each independent variable in all three estimations methods. In developing Asia, we find a statistically significant elasticity of FDI with respect to all three variables of interest, namely changes in the official (nominal) exchange rate, real interest rates and GDP growth. These are the estimates used in our simulations. The signs of these elasticities are consistent with our explanation for the mechanism through which these variables affect FDI flows: A one percent higher real interest rate differential increases the change in FDI flows (\%GDP) from the previous year by 0.2 percent. We expect this elasticity to be positive, as capital flows to a country with lower asset prices. A one percent nominal devaluation (increase in average nominal exchange rate with respect to the previous year) increases the flows by 0.03 percent. We interpret this channel as the effect of the devaluation on the competitiveness of export sector. Finally, growth matters for FDI flows: a one percent higher GDP growth increases our dependent variable by 0.2 percent contemporaneously.

In other country groups, namely emerging market countries of G20 and OECD countries, the only significant relationship is between changes in FDI (\%GDP) with contemporaneous growth rate. Our interpretation of this result is that higher FDI each year is directly counted as higher investment in national accounting data. However, to the extent that there is serial correlation in growth rates, one hypothesis could be that higher growth this year would mean higher expected growth next year, which induced higher investment this year. It is also interesting to note that the elasticity of FDI (\%GDP) growth with respect to the GDP growth rate are of the same order of magnitude for the three country sets: efg is estimated to be between 0.10 and 0.25 depending on the particular specification and the region.

Finally, we should emphasize that the relationships we establish do not provide a robust explanation of cyclical changes in FDI flows. However, for the purposes of calibrating our model 
they provide us with a reasonable range of values. Our model converges for all the values in the confidence intervals of our point estimates.

\section{An Application}

In order to simulate our model we have used the data sources and parameter estimates described in the previous section. Thus we do not claim that our results have more than a tenuous relationship to any specific South Asian country. Rather, they should be used to give some descriptive policy suggestions for certain types of countries. ${ }^{24}$

\section{A. A Base-Case Simulation}

In order to use our model for counter-factual simulations, we first generate an equilibrium, using benchmark policy parameters, over an eight-year time horizon. ${ }^{25}$ We take initial allocations to have their values for China for 1996, and all government policy parameters also have Chinese values. We take tax rates to have their estimated effective values. Government current and capital expenditures are given their historical values, and are assumed to be maintained at the same real level for all periods of the simulation. We also suppose that the Central Bank maintains a fixed exchange rate, in U.S. dollars, with the rate being fixed at the level of the first year. A sector is unable to repay its debt, as in Section III.D, when the present value of the future stream of earnings from the investment becomes less than the corresponding debt obligations. Finally, we will suppose that the bank solvency requirement, $\alpha$ as in Section III.B, is 8 percent. Thus if a bank's non-performing assets are greater than 8 percent of its total assets, then a portion of the bank's deposits are seized and depositors are unable to retrieve that share of their assets.

As in Section III.B, if the bank's borrowers default on their loans, then the bank loses $\omega_{K} D E F_{K i}$ of its deposits, resulting in a wealth shock to depositors. In order to be specific, we will let $\omega_{K}=1$ for all banks. We will suppose that banks do not ration credit when their borrowers begin to default. Table 2 reports the simulation outcomes for the main macroeconomic variables for this base case.

\footnotetext{
${ }^{24} \mathrm{We}$ conducted all the experiments with a labor-leisure elasticity of zero as opposed to 0.5 corresponding to the experiments demonstrated here. None of the qualitative results are altered.

${ }^{25}$ We take 1995 Chinese data for initial stocks in the base year.
} 
Table 2. Base Case

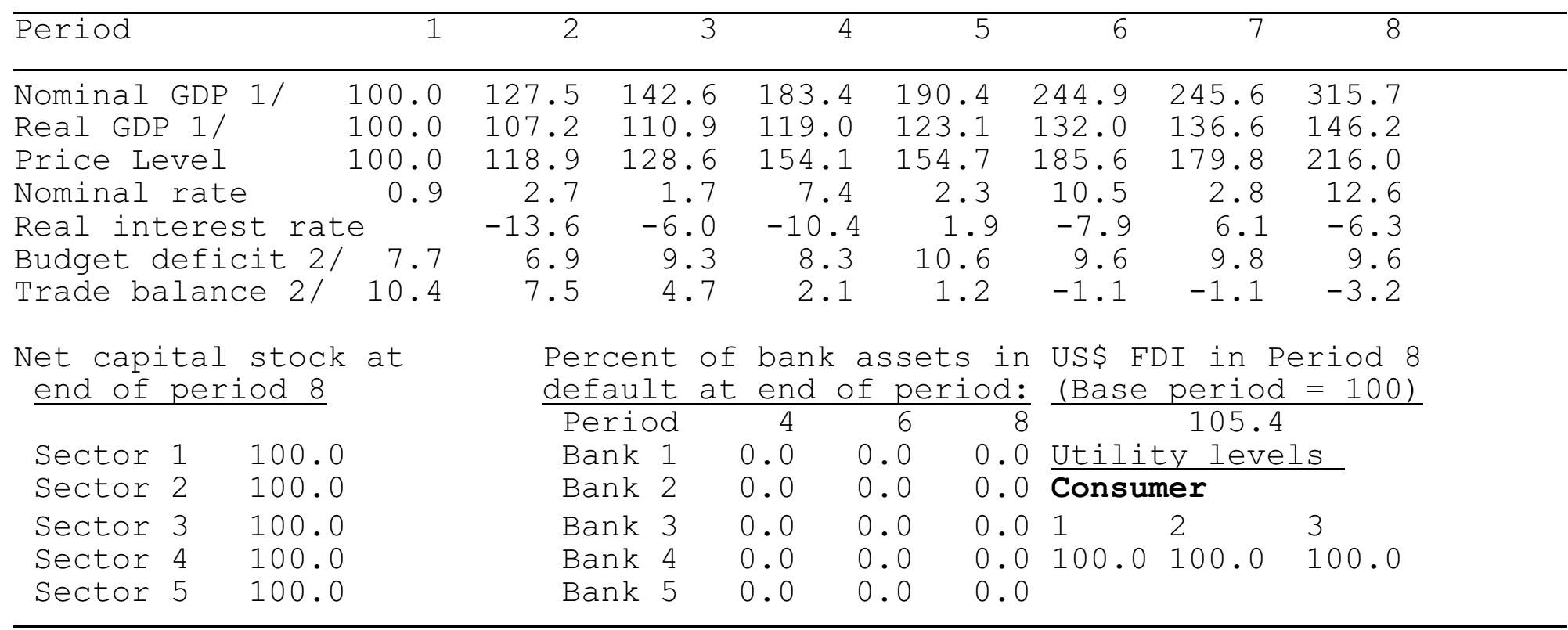

1/ All indices are normalized for this base simulation.

2/ As a percentage of GDP.

We notice that our model generates moderate rates of growth in real GDP, with the average rate over the 8 years being 5.6 percent. The budget deficit rises slightly, and then stabilizes, while interest rates rise somewhat, in response to the higher budget deficit. The trade surplus disappears, and is replaced by a deficit as the fixed exchange rate becomes overvalued. ${ }^{26}$ No borrower defaults on his loan and no bank fails. FDI gradually rises over time, as the average domestic interest rate is 5.1 percent, higher than the assumed US interest rate of 2 percent. Hence domestic assets are cheaper than foreign assets, given the fixed exchange rate. At the same time there is positive growth, also leading to an increase in FDI.

Before analyzing the policy experiments, two points are worth emphasizing here as they clarify some of the seemingly counter intuitive results. The first is related to changes in domestic vs foreign investment: while the foreign investor cares about nominal interest rates, only real interest rates matter for the domestic investor's decision. This is because the foreign investor borrows abroad, at the assumed constant nominal rate of 2 percent, to finance his purchase of an asset in the domestic currency. His rate of return, therefore, is determined by the difference between the nominal increase in the price of the asset converted into dollars, less the 2 percent paid on borrowed funds. Thus, the foreign investor cares about nominal domestic rates as well as exchange rates. Whereas the domestic investor borrows by issuing domestic currency denominated bonds, on which she pays domestic nominal rates, to finance her purchases of

\footnotetext{
${ }^{26}$ Average annual inflation is 11.6 percent, while we have assumed foreign inflation to be 2 percent.
} 
assets, on which she earns the real rate plus inflation in prices. Hence only the real interest rate matters for her investment decision.

The second observation is that domestic investment can rise following a revaluation, despite rising real interest rates. The explanation here is that the income effect of a revaluation allows the agent to increase both his consumption expenditure (on cheaper imported goods) and investment. This will not necessarily be the case for all choices of labor-leisure elasticities.

\section{B. Increasing Consumption by a Revaluation}

Suppose now that the authorities decide to carry out a revaluation of the exchange rate. They might do so as a way to increase domestic consumption and welfare, or to reduce FDI. As an illustrative example, we carry out an annual revaluation of 9.5 percent. ${ }^{27}$ All exogenous parameters, other than those having to do with the open market operation, remain the same as in the previous exercise. Table 3 gives the results of this exercise.

Table 3. 9.5 Percent Revaluation

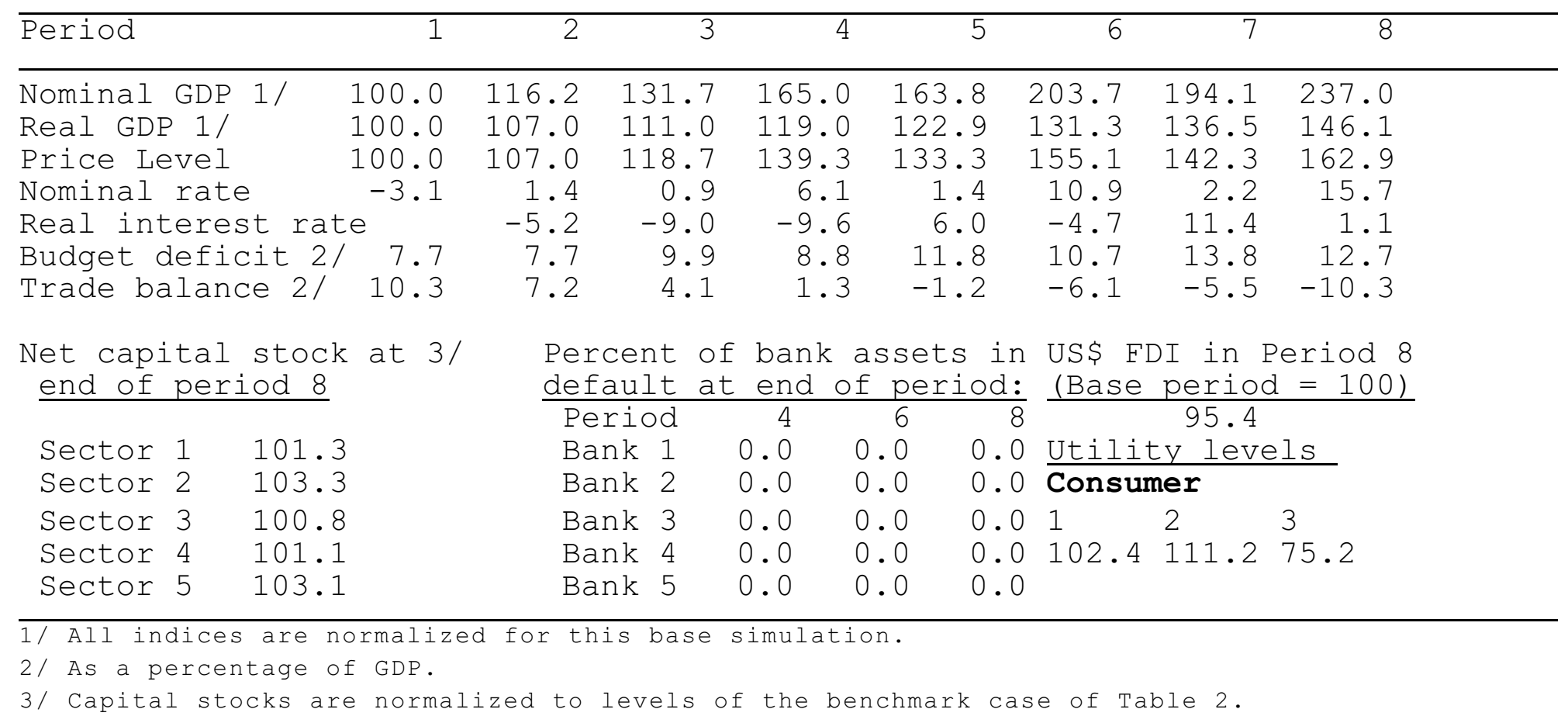

We notice a number of changes, as compared to the benchmark case of Table 2 . The revaluation has caused a considerable deterioration in the trade balance, as might be expected. In addition, FDI is now lower in the final period than in period 1. Although nominal interest rates

${ }^{27}$ Thus if the exchange rate was fixed at 100 in the base case, then the new exchange rate series becomes 100 , $90.5,81.9,74.1, \ldots$. 
are rising, revaluation of the domestic currency is high enough to reduce FDI flows. FDI is also significantly lower than the final period outcome in Table 2, as asset prices continue to rise for the foreign investor, both through a nominal revaluation and a lower nominal interest rate compared to the base case. Rising demand for imports has caused consumption of domestic output to decline. The real value of savings rises, as does domestic investment which more than substitutes for the FDI decline. As a result, there has been a moderate increase in end of period sectoral capital stocks. Note that this is consistent with the intuition we provided above: real interest rates, which have risen in this case relative to the base case, are the determining factor for domestic investors. There have been welfare gains for both domestic consumers.

How far can the revaluation be pushed while still remaining economically viable? Suppose as a final experiment we increase the rate of revaluation to 10 percent annually. Table 4 gives the results.

\section{Table 4. 10.0 Percent Revaluation}

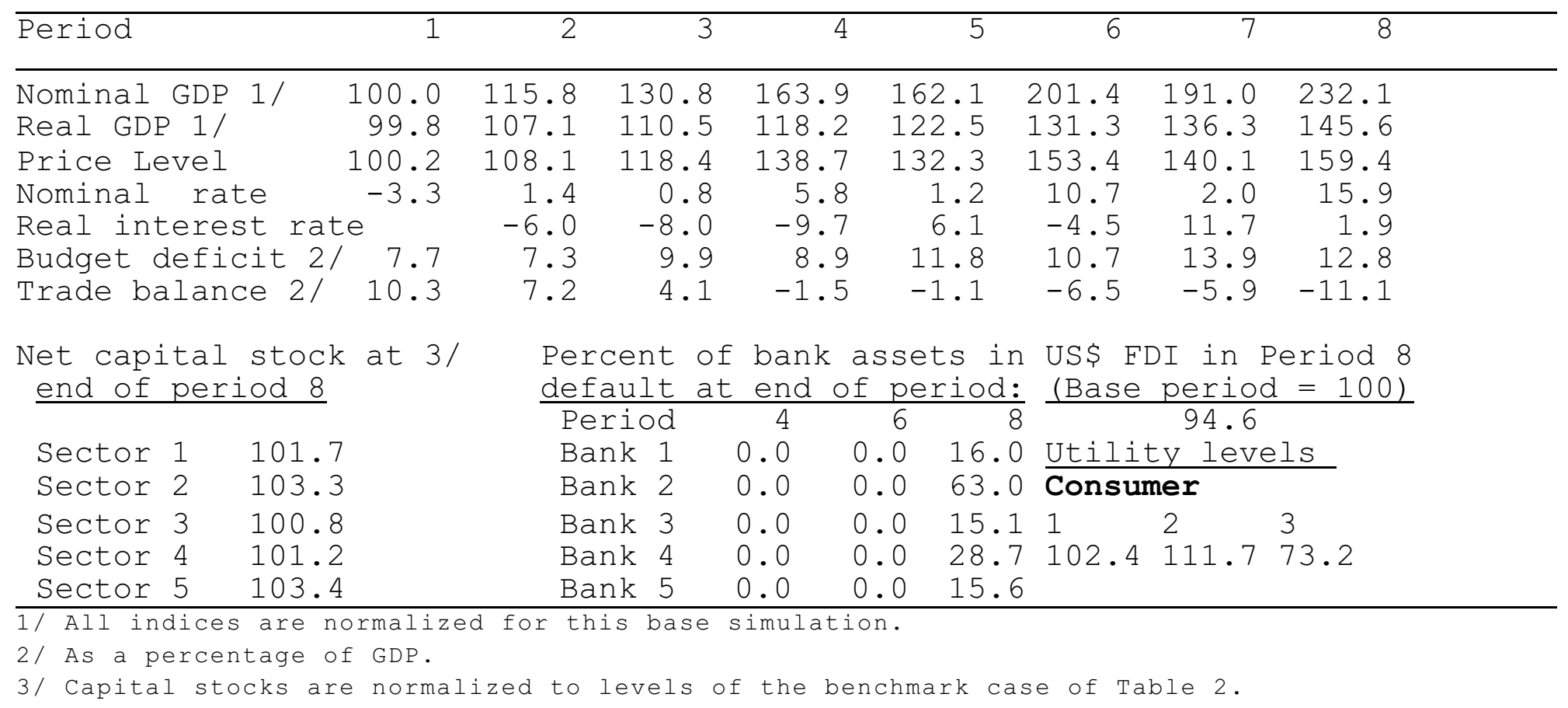

Real GDP continues to decline, as compared to Table 4, and the trade balance deteriorates further. FDI also declines compared to the base case, as well as to Table 4, due to the increased price of domestic assets. Consumption of domestic output continues to decline, while savings increase, leading to yet higher domestic investment that replaces FDI. As a result, the rate of return on domestic investment declines, and real interest rates continue to rise. By the final period sector 2 defaults on its debts. Sector 2 (manufacturing) is large relative to the economy so its default spreads across all banks, each of which is now above the 8 percent failure rate. Accordingly, the entire banking system has now collapsed. We also notice that each consumer 
has realized an intertemporal utility increase, given the decrease in the price of imports, despite the fact that real GDP has slowed. Essentially cheap imports have substituted for domestic output, and there has been an increase in consumption of leisure.

Of course this new outcome is not sustainable, so we need to ask if it is possible to achieve similar welfare gains by policies other than exchange rate revaluations. ${ }^{28}$ There are many such potential policies, and it is not possible to analytically solve for particular tax rates or spending levels that will give a particular welfare outcome. However, as a simple example of what could be accomplished by increasing consumption, we will impose a decrease in the personal income tax. The assumed effective tax rate on personal income was 5 percent in the previous examples. We will now suppose that it is reduced to 3 percent. The outcome is given in Table 5.

Table 5. Personal Income Tax Reduction

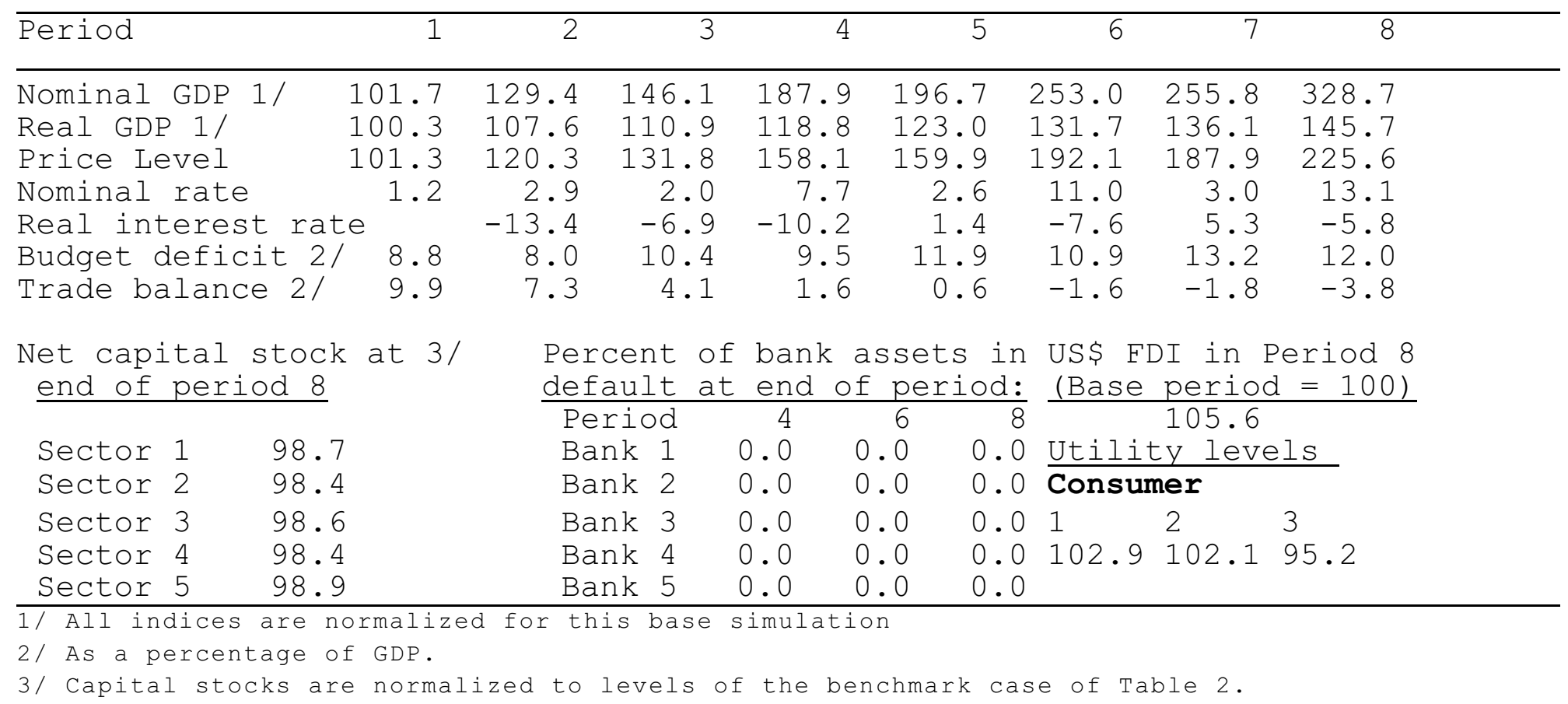

As expected, the budget deficit rises compared to the case of Table 2. Following a tax cut GDP rises initially relative to the base case, as it is expected. However, due to rising budget deficit, the final period GDP is lower than that in the base case (see Figure 1). This is also intuitive: As the government issues debt to monetize the deficit interest rates rise, slowing down capital formation.

The increase in nominal interest rates has caused FDI to increase, as compared to the

\footnotetext{
${ }^{28}$ Many countries may object to revaluations for other reasons than their potential for causing financial instability.
} 
benchmark case, although the decline in domestic investment is greater than the increase in FDI due to rising real interest rates. Lower levels of borrowing by domestic investors have caused no loan defaults, and the banking system is solvent. Consumer 1 (urban), is at approximately the same utility level as in Table 3, although Consumer 2 is at a lower level. The trade balance improves significantly, and is only slightly lower than in the base case of Table 2 . The small deficit is because of lower exports: a higher price level combined with fixed exchange rates means higher export prices for the foreigners. Thus the tax cut has achieved the objective of increasing consumption, as reflected in higher utility for both consumers. Consumer 1 is better off with the tax cut than with the revaluation, while the opposite is true for Consumer 2.

We thus have an indication that it is possible to have general intertemporal welfare increases, without financial failures, by the use of fiscal policy in the form of tax changes. Exchange rate changes, in the form of revaluations, may lead to larger welfare gains by certain

\section{Figure 1. Real GDP Series Following a Tax Cut \\ ( $\%$ change relative the base case)}

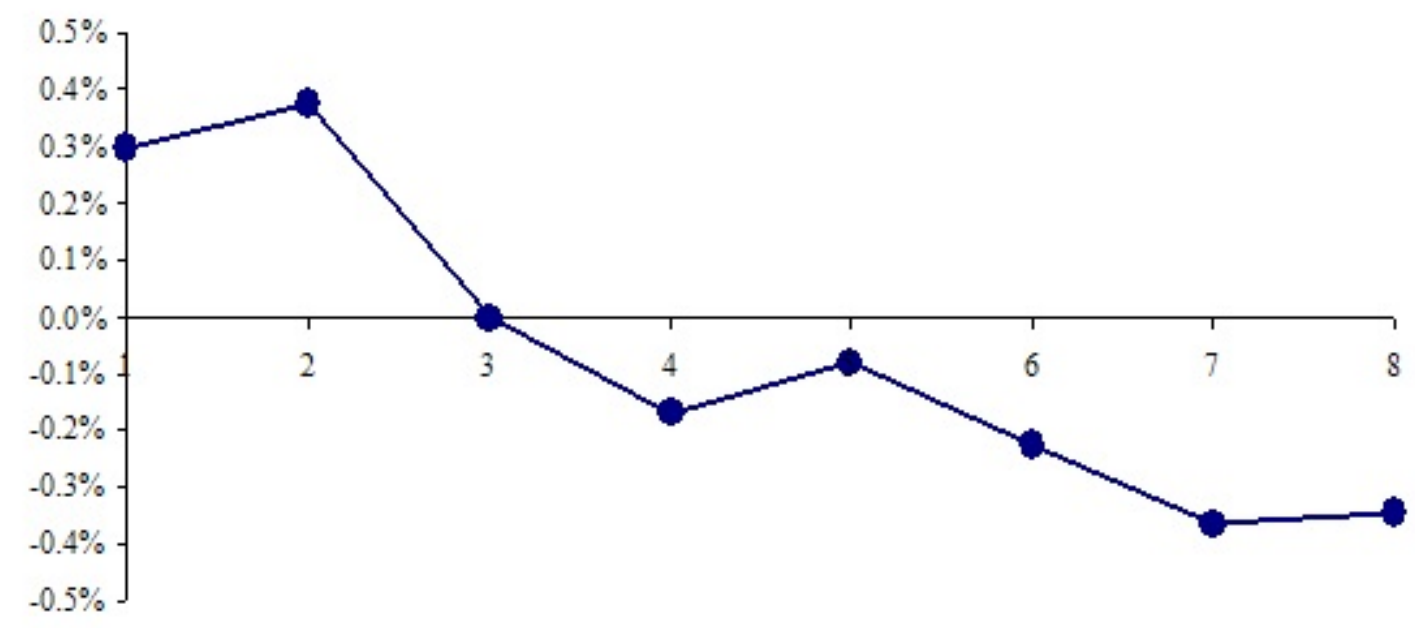

consumer categories, but can become financially unsustainable.

\section{Conclusion}

This paper has developed a model for the analysis of certain policy instruments that have been used to stimulate growth and consumption in certain East Asian economies. These instruments have sometimes been introduced in response to existing market distortions and their potentially adverse consequences. Thus, for example, under-valued fixed exchange rates may have been used as a way to induce high savings and investment rates. Similarly, high rates of return on capital caused by surplus labor, combined with the under-valued exchange rate, have 
attracted foreign direct investment (FDI). Existing investors have suffered losses on their investments, as the return to capital eventually falls. These losses, and resulting inability to service debt, have resulted in bank failures.

We have analyzed the welfare implications of alternative paths to the goals of increased consumption and financial stability. We have considered policies leading to an increase in the consumption level, since they are currently viewed as being key instruments in avoiding the financial difficulties that will eventually arise from excessive savings and investment rates. We have developed an intertemporal general equilibrium model that can generate endogenous bank failures, and which allows alternative policies to compensate for these failures. The model incorporates endogenous FDI, that is itself a function of domestic growth, as well as domestic and foreign interest rate differentials. A benchmark simulation of the model generates rapid growth, in response to stylized economic policies. We then have imposed fiscal and exchange rate policies that can be used to achieve increased levels of private consumption, while maintaining high growth rates and avoiding financial collapse.

The simulations indicate that it is possible to have general intertemporal welfare increases, without financial failures, by the use of fiscal policy in the form of tax changes. Exchange rate changes, in the form of revaluations, may lead to larger welfare gains by certain consumer categories, but can become financially unsustainable. 
Appendix

Table 1. Consumption by Region and Source as a Share of GDP (Average 2001-05)

$\begin{array}{lccc} & \text { Household } & \text { Government } & \text { Total } \\ \text { China } & 44.8 & 14.1 & 58.9 \\ \text { Korea } & 53.7 & 13.3 & 67.1 \\ \text { India } & 62.5 & 11.7 & 74.1 \\ \text { Malaysia } & 43.9 & 13.3 & 57.2 \\ \text { Thailand } & 57.1 & 11.2 & 68.3 \\ & & & \\ \text { Canada } & 55.1 & 19.1 & 74.2 \\ \text { Germany } & 56.9 & 19.0 & 75.9 \\ \text { Japan } & 55.6 & 17.7 & 73.3 \\ \text { UK } & 64.4 & 19.4 & 83.8 \\ \text { US } & 71.0 & 15.0 & 85.9 \\ & & & \\ \text { OECD Average } & 56.1 & 18.6 & 74.6 \\ \text { EURO Area } & 56.4 & 20.0 & 76.4 \\ \text { Source: OECD database, and ADB. } & \end{array}$

Table 2. Gross National Savings and Investment as a Share of GDP (Average 2001-05)

$\begin{array}{lcc} & \text { Savings } & \text { Investment } \\ \text { China } & 42.1 & 43.4 \\ \text { Korea } & 32.6 & 29.8 \\ \text { India } & 26.3 & 10.8 \\ \text { Malaysia } & 36.3 & 0.5 \\ \text { Thailand } & 28.0 & 26.3 \\ \text { Canada } & 22.2 & 20.1 \\ \text { Germany } & 20.2 & 17.7 \\ \text { Japan } & 26.5 & 23.4 \\ \text { UK } & 15.1 & 16.9 \\ \text { US } & 14.0 & 19.0 \\ & & \\ \text { urce: International Monetary Fund, World Economic Outlook } \\ \text { tabase, April 2007 and ADB. }\end{array}$


Appendix

Figure 1. FDI (\% GDP)

Panel Data from OECD (top panel) and East Asia (bottom panel)

\author{
$\mathrm{FDI}(\% \mathrm{GDP})$ \\ Pand data from $O E C D$
}

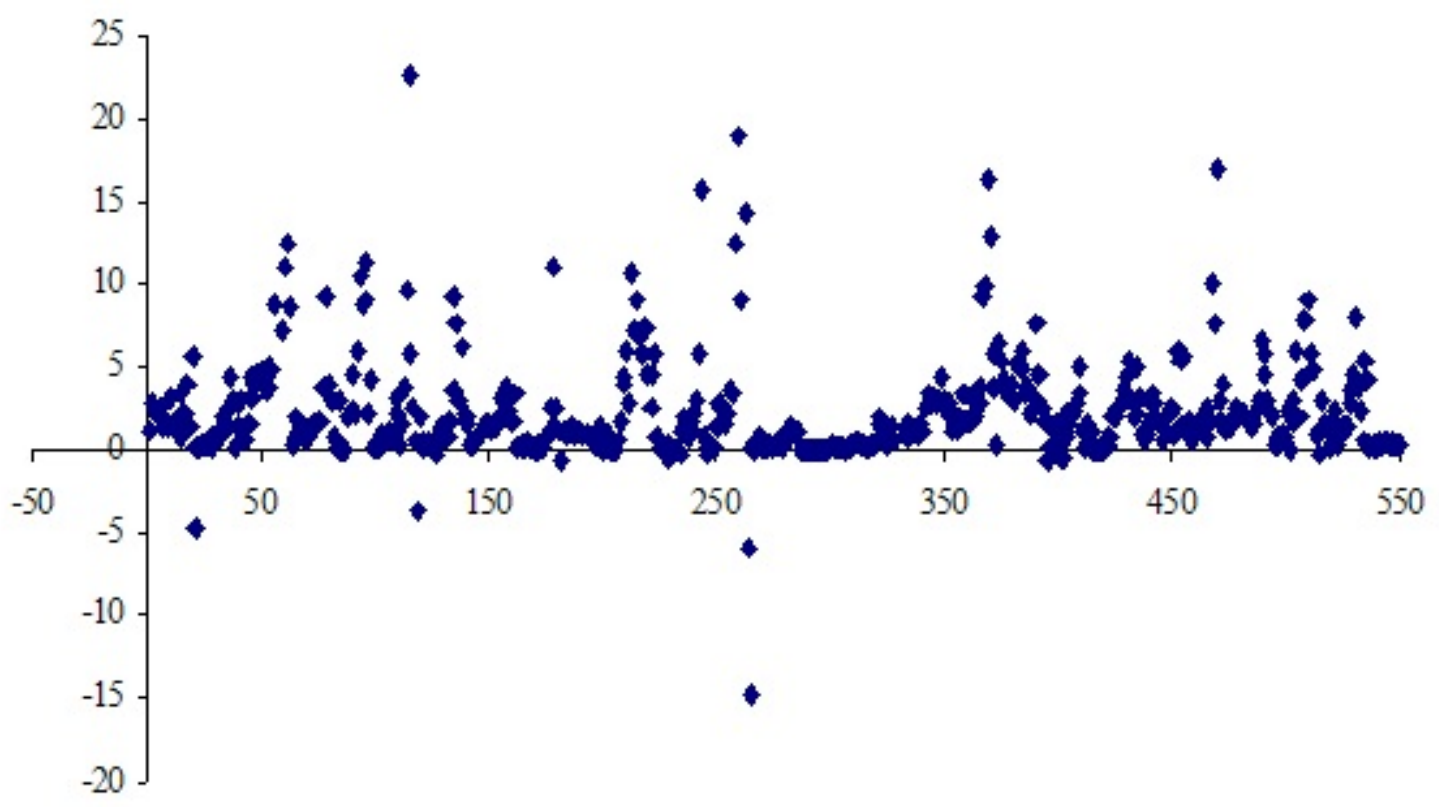


Appendix

Figure 2. First Differenced FDI (\% GDP)

Panel data from OECD (top panel) and East Asia (bottom panel)

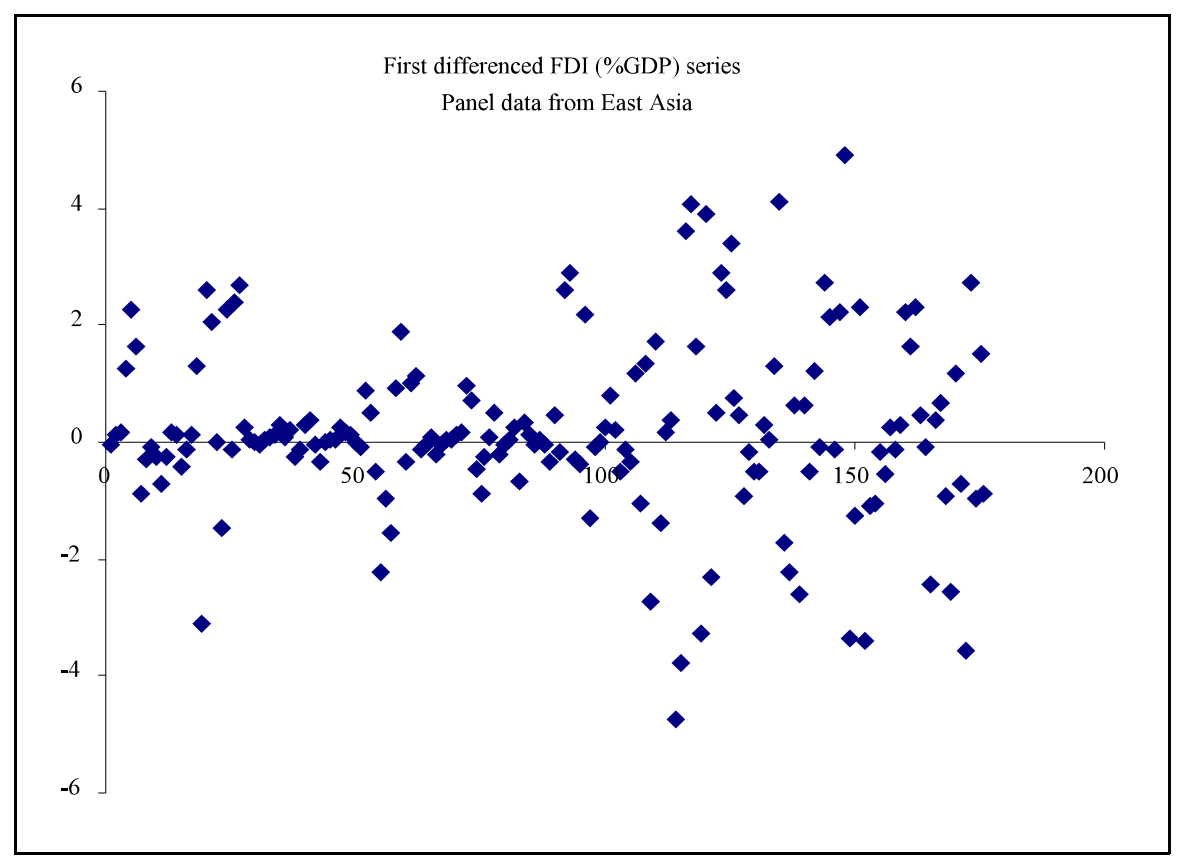




\section{References}

Ball, S., and A. Feltenstein (2001), "Bank Failures and Fiscal Austerity: Policy Prescriptions for a Developing Country," Journal of Public Economics, 82 (November), pp. 247-70.

Bergstrand, J.H.and Egger, P. (2007), “A Knowledge-and-Physical-Capital Model of International Trade, Foreign Direct Investment, and Foreign Affiliate Sales: Developed Countries," Journal of International Economics, 2007, forthcoming.

Blejer, M, E. Feldman, and A. Feltenstein (2002), "Exogenous Shocks, Contagion, and Bank Soundness: A Macroeconomic Framework," Journal of International Money and Finance, vol. 22, pp. 33-52.

Blonigen, B. A., (1997), "Firm-Specific Assets and the Link between Exchange Rates and Foreign Direct Investment," American Economic Review, American Economic Association, vol. 87(3), pages 447-65.

Blonigen, B. A., (2005), “A Review of the Empirical Literature on FDI Determinants,” NBER Working Paper No. W11299, National Bureau of Economic Research.

Calormiris, C., and B. Wilson (1998), "Bank Capital and Portfolio Management: The 1930's Capital Crunch and Scramble to Shed Risk," NBER Working Paper No. W6649, July National Bureau of Economic Research.

Eichengreen, B. \& H. Tong, (2005), "Is China's FDI coming at the expense of other countries?" NBER Working Papers 11335, National Bureau of Economic Research.

Ekholm, K. \& R. Forslid \& J. Markusen, (2003), "Export-Platform Foreign Direct Investment," NBER Working Papers 9517, National Bureau of Economic Research.

Feltenstein, A., S.M. Nsouli (2003), “'Big Bang” versus Gradualism in Economic Reforms: an Intertemporal Analysis with an Application to China," IMF Staff Papers, Vol. 50, No.3, pp. 458-80.

Froot, K. A. \& J. Stein, (1991), "Exchange Rates and Foreign Direct Investment: An Imperfect Capital Markets Approach," The Quarterly Journal of Economics, MIT Press, vol. 106(4), pages 1191-217.

Fung, K. C., H. Iizaka, \& S. Parker, (2002), "Determinants of U.S. and Japanese Direct Investment in China", Journal of Comparative Economics, Elsevier, vol. 30(3), pages 567-578. 
Hanson, G. H. \& R. J. Mataloni, Jr. \& M. J. Slaughter, (2001), "Expansion Strategies of U.S. Multinational Firms," NBER Working Papers 8433, National Bureau of Economic Research.

Kuijs, L. (2005), “Investment and Saving in China,” Working Paper 3633, World Bank Policy Research.

Kydland, F., and E. Prescott (1977), "Rules Rather than Discretion: The Inconsistency of Optimal Plans," Journal of Political Economy vol. 85, no. 3, June 1977, pp. 473-491.

Lane, P.R. \& S.L. Schmukler, (2006), "The International Financial Integration of China and India," CEPR Discussion Papers 5852, C.E.P.R. Discussion Papers.

Leonard K.C. \& Y. K. Kwan, (1998), "What Are The Determinants of The Location of Foreign Direct Investment? The Chinese Experience," Finance Working Papers 174, East Asian Bureau of Economic Research.

Markusen, J. R. \& K.E. Maskus, (1999), "Multinational Firms: Reconciling Theory and Evidence," NBER Working Paper No. W7163, National Bureau of Economic Research.

Markusen, J., C. Ekholm \& R. Forslid, (2007), "Export-Platform Foreign Direct Investment," Journal of the European Economic Association, MIT Press, vol. 5(4), pages 776-795.

Nunnenkamp, P. , (2002), "Determinants of FDI in Developing Countries: Has Globalization Changed the Rules of the Game?," Kiel Institute for World Economics, Kiel Working Paper No. 1122.

Strotz, R. (1956), "Myopia and Inconsistency in Dynamic Utility Maximization," Review of Economic Studies, vol. 23 (3), no. 62, pp.165-180.

Whalley, J. \& X. Xin, (2006), “China's FDI and Non-FDI Economies and the Sustainability of Future High Chinese Growth," NBER Working Papers 12249, National Bureau of Economic Research.

Zhang, K. H. \& S. Song, (2001), "Promoting Exports: the Role of Inward FDI in China," China Economic Review, Elsevier, vol. 11(4), pages 385-396.

Regional Economic Outlook: Asia and Pacific (2006), International Monetary Fund.

World Economic Outlook (2005), International Monetary Fund. 